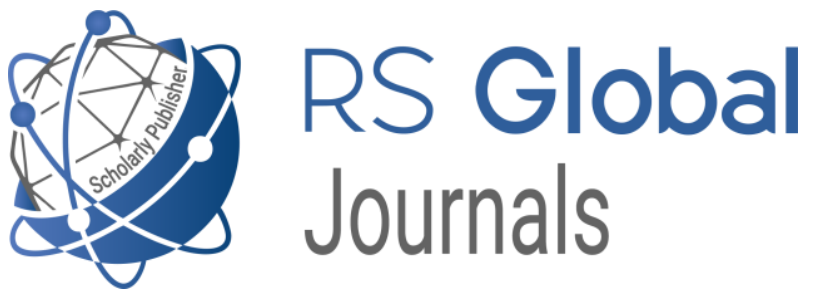

Scholarly Publisher

RS Global Sp. z O.O.

ISNI: 0000000484952390

Dolna 17, Warsaw, Poland 00-773

Tel: +48226022703

Email: editorial_office@rsglobal.pl

JOURNAL International Journal of Innovative Technologies in Social Science

p-ISSN 2544-9338

e-ISSN 2544-9435

PUBLISHER RS Global Sp. z O.O., Poland

ARTICLE TITLE HEYDAR ALIYEV AS A FOUNDER OF NATIONAL MULTICULTURALISM AT THE STATE LEVEL

AUTHOR(S) Abilova Zulfiyya Mammad

Abilova Zulfiyya Mammad. (2020) Heydar Aliyev as a Founder

ARTICLE INFO of National Multiculturalism at the State Level. International Journal of Innovative Technologies in Social Science. 7(28). doi: 10.31435/rsglobal_ijitss/30122020/7233

DOI https://doi.org/10.31435/rsglobal_ijitss/30122020/7233

RECEIVED

22 September 2020

ACCEPTED

11 November 2020

PUBLISHED

16 November 2020

(c) (i)

LICENSE

This work is licensed under a Creative Commons Attribution 4.0 International License.

(C) The author(s) 2020. This publication is an open access article. 


\title{
HEYDAR ALIYEV AS A FOUNDER OF NATIONAL MULTICULTURALISM AT THE STATE LEVEL
}

\author{
Abilova Zulfiyya Mammad, \\ PhD student at Odlar Yurdu University, English Language Lecturer at Azerbaijan State Pedagogical \\ University, Azerbaijan, Baku
}

DOI: https://doi.org/10.31435/rsglobal_ijitss/30122020/7233

\section{ARTICLE INFO}

Received 22 September 2020

Accepted 11 November 2020

Published 16 November 2020

\section{KEYWORDS}

Globalization, tolerance, relations, constitution, equality, multiculturalism, peaceful existence.

\begin{abstract}
The presented scientific article states that one of the main tasks of states is achieving tolerance in human relations and creating favorable conditions for people of different religions and cultures to live in peaceful environment. Azerbaijan has historically been a space where representatives of different ethnic groups and religions lived in an atmosphere of peace and friendship. Heydar Aliyev chose the exact ideological goal of the future successful development of Azerbaijan and, with his far-sighted and wise policy, developed the tradition of multiculturalism that had formed over the centuries and raised it to a qualitatively new stage.
\end{abstract}

Citation: Abilova Zulfiyya Mammad. (2020) Heydar Aliyev as a Founder of National Multiculturalism at the State Level. International Journal of Innovative Technologies in Social Science. 7(28). doi: 10.31435/rsglobal_ijitss/30122020/7233

Copyright: (C) 2020 Abilova Zulfiyya Mammad. This is an open-access article distributed under the terms of the Creative Commons Attribution License (CC BY). The use, distribution or reproduction in other forums is permitted, provided the original author(s) or licensor are credited and that the original publication in this journal is cited, in accordance with accepted academic practice. No use, distribution or reproduction is permitted which does not comply with these terms.

Introduction. People have to be provided with kindness and mutual understanding in order to maintain stability in the world. A society which is disrespectful to different cultures and traditions, as well as to the beliefs and ideas of those who practice other religions, will never be able to achieve stability and development. One of the main objectives of the state and all peoples of our time is achieving tolerance in human relations, providing people of different religions and cultures being able to live in the peaceful environment. It is obvious that if there is a problem of tolerance in society, relations between people will be getting worse and it can create new conflicts throughout the world. In order to avoid conflicts, tolerance and respect to different religions and cultures have to be at the first place. Therefore, in the period of globalization issues related to multiculturalism, occupy a special place.

Presentation of the man material. The Republic of Azerbaijan is a tolerant and multinational country with deep multicultural values, spiritual heritage and rich culture. It is the place where various people, nations, races and religions can live peacefully all together. Azerbaijan has a very unique cultural space, where a number of national-ethnic groups can live peacefully. Azerbaijan is inhabited not only by Azerbaijanis, but also by other nations and ethnic groups, which live both in the capital city and different regions of our country. All these people are considered to be equal citizens of Azerbaijan. Their rights are not infringed upon them and due to the Article 69 in the Constitution of the Republic of Azerbaijan which is titled- Right of foreign citizens and stateless persons: Foreign citizens and stateless persons staying in the Azerbaijan Republic may enjoy all rights and must fulfill all obligations like citizens of the Azerbaijan Republic if not specified by legislation or international agreement in which the Azerbaijan Republic is one of the parties [11]. Even after Azerbaijan gained its state independence on 28 May 1918, unlike many other countries, the culture of the ethnic minorities and ethnic groups living here was protected and developed as a component of culture of the country [11, 93-94]. 
Multiculturalism is a unique phenomenon, which helps to preserve peaceful existence between different countries, religions, cultures and nations. Multiculturalism is closely connected with tolerance. Azerbaijan is considered as one of the most tolerant countries. "I consider that the Azerbaijani people, by their nature and character have high sense of tolerance." By this statement, our Great Leader Heydar Aliyev displayed relations to world values and showed that regardless of nationality and religion, the Republic of Azerbaijan can be the homeland to representatives of various people. And nowadays, Azerbaijan is still the place where different nationalities have a great opportunity not only to live peacefully, but also to work and have an education. "Multiculturalism is a way of life in Azerbaijan. It may be a relatively new term but over the course of centuries Azerbaijan has had a multicultural society. Clear evidence of this is the friendship and solidarity among peoples. We are still committed to ensuring that our initiatives have a positive impact on the processes taking place in the region and the world at large", said the President of Azerbaijan Republic Ilham Aliyev in his speech at an official opening ceremony of the 4th Baku International Humanitarian Forum [12]. Actually, this is the reality which belongs to our country. And from my personal prospective, this fact should be regarded as the fact which deserves approval, respect and honor. The ideology of supporting this phenomenon at the state level was established by the National Leader of the Azerbaijani people Heydar Aliyev, and now successfully continues by the President of the Republic of Azerbaijan Ilham Aliyev. Azerbaijan society was always multicultural, tolerant and respectful to all religions and cultures, that's why on the order of the President of the Republic of Azerbaijan of January 11, 2016, that year was declared as "The Year of Multiculturalism" and he said that Azerbaijan is a model country in terms of multiculturalism, religious and national tolerance in the world.

Azerbaijan is a country where from ancient times people of various religions and cultures live together in the atmosphere of peace and kindness. Year after year this factor led to the formation of interpersonal, intercultural and interreligious understanding between people [1, 17]. Multiculturalism is thriving, improving and strengthening in Azerbaijan, because there are all conditions for it, such as tolerance or political and economic conditions. On September 8, 2016, the President Ilham Aliyev told that "Azerbaijan is known worldwide as a country of national, religious and ethnic tolerance and brotherhood. This is already a reality, especially in the present circumstances, when there are standoffs in various parts of the world. There are wars on religious and ethnic grounds. Azerbaijan is showing an example in this area as well".

Currently, Azerbaijan is known worldwide not only as a country with rich natural and energy resources, but also as a country which is tolerantly and multiculturally developed. Heydar Aliyev chose the exact ideological goal of the future successful development of Azerbaijan and by his far-sighted, wise policy, could develop the tradition of multiculturalism that was formed over the centuries and raised it to a qualitatively new stage. Heydar Aliyev is the Great Leader and political founder of Azerbaijani multiculturalism. At the initiative and direction of Heydar Aliyev, a legitimate ground was created for the preservation and development of literature, culture, language, history, customs and traditions of national minorities. Multiculturalism is not only the lifestyle of Azerbaijani people, but it is also one of the Articles in the Constitution of the Azerbaijan Republic which was enacted by the initiative of Great Leader Heydar Aliyev. According to this Article 25, which is titled as Right for equality:

I. All people are equal with respect to the law and law court.

II. Men and women possess equal rights and liberties.

III. The state guarantees equality of rights and liberties of everyone, irrespective of race, nationality, religion, language, sex, origin, financial position, occupation, political convictions, membership in political parties, trade unions and other public organizations. Rights and liberties of a person, citizen cannot be restricted due to race, nationality, religion, language, sex, origin, conviction, political and social belonging.

IV. No one may be harmed, granted allowances or privileges, or deprived from granting allowances and privileges on the basis of the grounds elaborated in Part III of this Article.

V. Equal rights shall be provided for everyone in relationship to the state institutions making decisions on rights and responsibilities and those having the competencies of state authority [11].

All this means, that it is guaranteed respect for the rights and freedom of everyone, regardless of origin, race, religion and language. Along with this, in many laws adopted after the return of the Great Leader Heydar Aliyev to power, the cultural identity of all national minorities living on the territory of 
Azerbaijan was guaranteed. The policy of the National Leader Heydar Aliyev, connected with national minorities in Azerbaijan, has always been positively perceived by international structures.

Conclusions. In conclusion, I would like to say that Azerbaijan is a unique space, a unique community of different peoples and religions. The history of our country does not know clashes and discriminations on ethnic or religious grounds. Today, all the people living in our country have the opportunity to develop their national culture, their language. Being a Muslim country, along with mosques, there are churches and synagogues. Surely, the regulation of relations between the state and religion in our country, the achievement of stability in the religious sphere, the preservation of the atmosphere of tolerance between religions at the state level are connected with the name of Heydar Aliyev. Now this policy is successfully continued by the President of the Azerbaijan Republic Ilham Aliyev. Till now, the composition of the Azerbaijani population is rich, both from ethnic, religious and confessional points of view.

\section{REFERENCES}

1. Azərbaycançılıq - birliyimizin əsasıdır, "Azərbaycan” nəşriyyatı, 2002, 34 səh.

2. Azərbaycan Respublikasının Prezidenti İlham Oliyev multikulturalizmin Azərbaycan modeli haqqında: Seçilmiş fikirlər (Azərbaycan, rus və ingilis dillərində). Bakı: Bakı Beynəlxalq Multikulturalizm Mərkəzi, 2017. - 528səh.

3. Heydər Oliyev siyasəti: Tolerantlıq (çıxışlar, nitqlər, görüşlər, təbriklər) Bakı, "Elm və Təhsil" - 2015, 504 səh.

4. Гейдар Алиев. Наша Независимость вечна, кн.V, Баку, Азернешр, 1998, 320 с.

5. Иманов, К. Заметки о мультикультурализме/ Баку 2016, 44 с.

6. Иманов, К. Об азербайджанской модели мультикультурализма (на основе данных об идентичности) 16 с.

7. Мамедов, Ф. Культуралогия. / «Симург», Баку, 2002, 101с.

8. Мехтиев, Р. Азербайджан: вызовы глобализации. / Баку. «XXI - Yeni nəşrlər evi», 2004 г., $584 c$.

9. Министерство Культуры Азербайджанской Республики "Культурная политика в Азербайджане"/ Баку, "Нагыл Еви", 2004, 254 с.

10. Мультикультурализм: тенденции и реальность. / кол. авт.: А.Ализаде [и др.]; науч. ред.: И.Габиббейли, Н.Сотникова; НАНА, Ин-т Литературы им. Низами; Ставропольский филиал Моск. гос. пед. ун-та./ Баку, «Элм», 2016,192 с.

11. E-book: Constitution of the Republic of Azerbaijan. Retrieved from http://azerbaijan.az/portal/General/Constitution/doc/constitution_e.pdf

12. Retrieved from http://multiculturalism.preslib.az/en.htm 